DOI: $10.24234 /$ wisdom.v17i1.453

Yulia VORONTSOVA, Maria Adelaida GIL MARTÍNEZ, Artur ARAKELYAN, Ara YEREMYAN

\title{
PEDAGOGICAL CHALLENGES OF TRANSHUMANISM: POSSIBLE THREATS IN THE CONTEXT OF DIGITALIZATION
}

\begin{abstract}
The article focuses on issues related to the pedagogical challenges of transhumanism. The authors consider possible ways to ensure that students will have a high level of economic literacy in combination with morality. This will allow students to develop an idea of ethical consequences which arise from management decisions made in the context of digitalization. When teaching subjects related to economic cycles, a lecturer faces various challenges formed by the modern transhumanist concept. One of the challenges is to work with the "digital generation" without its knowledge and orientation to moral and ethical principles, especially when students are from non-humanitarian universities. The ability to feel and be aware of fairness and to prefer justice to unjustness is a characteristic gifted to a human being to maintain his or her own internal interests. Transferring this attitude to the company will influence and form its ethical and moral principles in creating and promoting a product aimed at removing the obstacles associated with physical inability. Ethical postulates in teaching economic disciplines will ensure that students realize the concept of acceptable limits for generating income from technological innovations in various sectors of digital economics. In addition, the article presents the advantages and disadvantages of such concepts as variability and alternative education, its national character, continuous education, and intercultural communication.
\end{abstract}

Keywords: artificial intelligence, challenges, company ethics, digital economy, economic disciplines, economic literacy, ethical \& moral principles, pedagogical challenges, permissible limit, transhumanism.

\section{Introduction}

Nowadays, in the digital era, such topics as design and high-tech production are playing a crucial role and changing our world. Over the course of this century, technology is becoming extremely important for human development. One of the important aspects relates to the automatization of processes in the global digital space, which concerns a person's ability to design systems, machines, software that can work separately without human participation and implement a variety of smart processes. The basis for such transformations is the concept of transhumanism, which raises a number of questions for lecturers of economic subjects, where ethics and morality should play a key role in making managerial decisions when achieving positive 
business results (Cortina, 2005).

However, in the lecturing process, a teacher faces various challenges formed by the modern transhumanist concept. Today, human nature is boiled down to its empirically observable qualities, to the biological and mechanistic vision of human. The transhumanistic vision denies the classical prospect of human nature and considers it as a permanent self-construction, using science and technology as allies. Transhumanism opposes itself to Christian morality (Diéguez, 2017), and is based on the search for the possible use of unlimited improvements, challenging ageing and death by using achievements of science and technology, which provide the appropriate and necessary tools to reach transhumanism goals (Vorontsova, Arakelyan, \& Baranov, 2020). One of such goals is the change in human values and way of thinking, including its confessional and cultural affiliation. This movement deconstructs established and accepted moral values. The negative effect of transhumanism can be estimated only if a student has significant knowledge for forming criteria that allow him (as a future manager) to predict the consequences of his future management decisions in the sphere of artificial intelligence. In other words, transhumanism provokes the transformation of students conscious (Bloom, 1987), which eventually leads to the fact that goal of education will no longer relate to the comprehension of the truth (Dugin, 2016).

To find a solution, it is necessary to identify problems that have a powerful impact on the formation of moral and ethical principles of Russian students from economic faculties. It is equally important to analyze dual meanings in notions used by transhumanism in the field of education.

\section{Pedagogical Challenges}

The problems have become more widespread, especially for lecturers who are teaching humanitarian subjects in non-economic universities. These problems are stimulated by the development of information technologies and the formation of the "digital generation" (Feltrero, 2018). As a result of digital technologies' impact on brain development and the health of a new generation, scientists have begun to pay more attention to the problem called "digital imbecility" (Spitzer, 2016). This also becomes a challenge to a lecturer, who is obliged to work with students who are not able to think critically, argue, and concentrate on one subject for a long time. An imbalance starts to appear between the teaching and learning models. There takes place also a change in the interaction between a lecturer and a student. Therefore, the dynamics of the presentation of material in the classroom is changing due to difficulties in perception. In addition, the methodology of interrogation with such learners requires collaborative actions from both sides: lecturer-student (vertical communication) and student-student (horizontal communication) as they should share ideas and be able to negotiate, i.e. to approach the learning process transversally. The basis for such interaction is the deeper understanding of main economic concepts and their roots in philosophical and religious concepts. This is necessary for future work in the company, as future management decisions consist of competent work with micro - or macro-economic problems and solutions to organizational or personnel problems that arise in companies for which it is vital to develop the concept of corporate social responsibility (further - CSR). CSR is a compendium of ethical and moral val- 
ues, which helps any organization to build its internal and external identity.

The introduction of transhumanism idea into the educational process has also resulted in fragmentation of knowledge, which does not allow students to develop critical and analytical thinking fully (Jacoby, 2008). These skills allow students to generalize various information and link different types of data via correlation, as well as determine the degree of their direct influence. At the same time, most Russian universities prefer to give inductive rather than deductive knowledge based on the practical examples from specific companies (real and specific experience of companies that are partners of the educational institution: Google, Toyota, etc.). During CSR analysis, one can see that it is often based on ethical and moral values (religious tolerance, justice, honesty) that characterize each of the values. Besides, this creates an opportunity to generate abstract knowledge that can be transferred to other business contexts. In addition, emergence and active lobbying transnational and intercultural technologies (Gil Martínez \& Vorontsova, 2020), which are accessible to any social layer, penetrate into all types of organizational entities and families without taking into account their political, ethical or religious differences, and appear to be another most difficult pedagogical challenges (Chetverikova, 2018). Meanwhile, the boundaries between national and global are blurred, and individual and transcendent values which build up cultural identity are ignored. Therefore, it is extremely important for a lecturer of economic disciplines to make sure that students acquire and learn to be guided by ethical and moral principles that allow them to actively use technological innovations while maintaining the balance between ethics and business profit.

\section{Analysis of Definitions Presented by Transhumanism in the Sphere of Education}

Transhumanism has a decisive influence on the study of disciplines, including economic ones, due to the ambiguity of definitions proposed by its concept in the sphere of education. In order to increase the level of economic knowledge among students, when considering alternative management solutions, including the study and analysis of the application of moral and ethical principles, it is necessary to assess the significance of these definitions that characterize the transhumanistic approach to education.

The study of literature has shown that the key definitions of transhumanism in education (Transhumanismo, los arquitectos del futuro, 2012), including economic ones, are variability and alternativeness, the national character of education, openness, and continuity. These definitions are dualistic (having both positive and negative meaning - Figure) and can have diametrically opposite goals: 


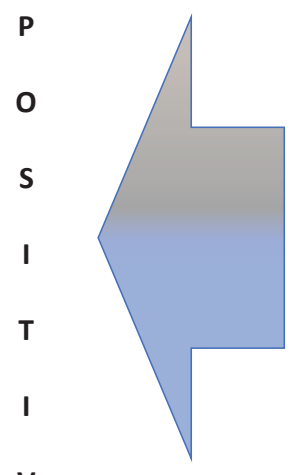

V
VARIABILITY OF EDUCATION

ALTERNATIVE EDUCATION

CONTINUING EDUCATION

OPENNESS OF EDUCATION

NATIONAL CHARACTER OF

EDUCATION

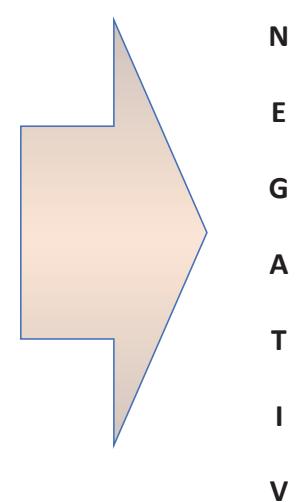

$\mathbf{N}$

E

G

A

I

V

Figure. Dual Meaning of Definitions Presented by

Transhumanism in the Sphere of Education.

- Variability of education implies a choice of educational subjects for students, which is a positive point. This allows students to study those subjects that are interesting for them and will be useful in the future. However, in practice, students make their choice in favour of more easy-to-understand disciplines or a less demanding lecturer, who, according to the concept of transhumanism, is no longer a source of knowledge for his students but rather appears to be a moderator who supports learning (Chetverikova, 2018);

- alternative education involves the use of non-traditional teaching methods. An alternative learning environment develops independence and creative thinking, and learning is a continuous lifelong process (Cortina, 2019). On the one hand, the path of self-development constantly changing and developing world of innovative technologies destroys traditional education system excepting possibility for a student to get necessary deep system pieces of knowledge that are being replaced by skills;

- continuing education lies at the heart of alternative education. As already mentioned in the analysis of the definition of "alternative education", a person is forced to study all his life. However, what is he learning? The concept of transhumanism implies continuous learning as a process of human adaptation to rapidly changing external global conditions of existence. Constant training makes a person be dependent on his constantly changing activities. In such conditions, a person is deprived of having an opportunity to lead a contemplative lifestyle, as he finds himself to be on the lower stages of the Maslow pyramid. This definition is closely connected to alternative education and, as a result, its global goal makes a person dependent on external conditions of dynamically changing environment, regardless of a person's inclinations, abilities and age;

- the openness of education implies transparency of a person's education throughout his or her life. This is closely related to the definition of continuous education and the consequences that follow the definition. Openness allows any interested person to track a person's successes/ failures throughout their life, which is a hidden form of control over an individual; 
- the national character of education. Blurring of borders and transition into global education according to the concept of transhumanism absolutely excludes the possibility of educating our children on traditional/national values that ensure continuity of generations. And here, transhumanism represents itself as a religion of modern global society (Santos, 2017).

\section{Formation of Ethical and Moral Principles in Students}

Given the information above, a lecturer needs to maximize positive aspects proposed by the concept of transhumanism and to minimize negative ones. To follow the idea, students of economic faculties should actively study various philosophical/religious trends and their ethical and moral principles, learn to distinguish between right and wrong and think critically. This becomes necessary in economic research, as it will be the basis for future business decisions when searching for the balance between purely human decisions and company goals.

Focusing on moral and ethical concepts, a lecturer of economic disciplines will direct views and efforts of students (future managers) to create a structure in which their management decisions will serve for obtaining technological innovations based on their maximum utility and benefits, on the one hand, and people's well-being, on the other hand. There is also an interesting point that even Elon Musk called the state (mostly graduates of economic universities) to interfere in the process of creating and developing innovative technologies (Morris, 2017). Therefore, the future manager should understand limits and permissions for using technological digital innovations rather than chase super high profits on their basis. For this purpose, one should be trained to measure the security level of using innovative technologies in the production and improvement process. Such measurements should be carried out by highly qualified personnel at the technical level and with the direct participation of the state as a regulatory body. This thesis also concerns the creation and use of artificial intelligence as one of the areas formed by the transhumanistic concept. And this is the main task of a lecturer. The ability to feel, reflect on justice, distinguish between fair and unfair is a human characteristic that makes it easier to understand the necessity of these actions. Justice, truth, and morality are valuable by themselves, and not only to the extent they are useful for life (Ortega y Gasset, 1963). If this principle is transferred to management decision-making, it can be very useful in creating, launching and promoting products that help fighting human physical defects. In other words, if these ethical principles of justice, truth and morality respect the local character of a project and absolute freedom of an individual, this will be a success for a lecturer of economic disciplines who faces problems outlined by transhumanism. In addition, guided by ethical principles in relations to balance and interdependence, one can talk about the maturity of global CSR, public and corporate benefits.

\section{Discussion}

The scientific novelty developed by the authors consists of conceptual and methodological propositions for organizing work with students of economic faculties within the framework of transhumanism concept, considering expansion of the humanitarian component in teaching of economic cycle disciplines. The authors have developed a number of pedagogical proposals that 
positively influence strong economic knowledge acquired by students under ethical and moral principles for their future work, in which management decisions will provide benefits from using technological innovations in terms of increased business profitability and balance for people's well-being.

\section{Conclusion}

Considering pedagogical challenges addressed by transhumanism which are associated with a fragmented knowledge of students, their weak ability to think critically and argue, the authors concluded that it is necessary to introduce the humanitarian component in teaching economic disciplines, which includes the study of subjects that can form students' moral and ethical principles. Transhumanist vision of education has a positive impact on individual development and related business achievements, but it does not promote individual freedom. Maximizing positive aspects of transhumanism notions and minimizing the negative ones, a lecturer guided by ethical principles of balance and interdependence will help students to create a system of social responsibility for governmental and corporate benefits in the future.

\section{Acknowledgement}

The results of the research were presented in the International forum "Transhumanism. Anthropological, Ethical, Legal and Theological Challenges" in Madrid, Spain (University Pontificia Comillas ICAI-ICADE, May 2019). The topic of the report was "Pedagogical Challenges of Transhumanism".

\section{References}

Bloom, A. (1987). The Closing of American Mind. New York, USA: Simon \& Schuster, Inc.

Chetverikova, O. N. (2018). Transgumanizm v rossiiskom obrazovanii: nashi deti kak tovar (Transhumanism in Russian Education: Our Children as a Commodity, in Russian). Moscow: Knizhnyi mir.

Cortina, A. (2005). Ética de la Empresa. Retrieved from https://www.academia.edu/21698754/Adela Cotina Orts Etica de la Empresa.

Cortina, A. (2019, February 26). Libertad en la era digital. Retrieved from https://elpais.com/elpais/2019/02/25/opinion/15 51096024 181754.html.

Diéguez, A. (2017). Transhumanismo. La búsqueda tecnológica del mejoramiento humano. Barcelona: Herder. Retrieved from https://doi.org/10.21555/top.v0i$\underline{56.1025 .}$.

Dugin, A. (2016, September 13). Transhumanismo. Retrieved from https://www.geopolitica.ru/es/directives/transhumanismo.

Feltrero, R. (Ed.). (2018). Tecnología e innovación social hacia un desarrollo inclusivo y sostenible. Madrid: Global Knowledge Academics.

Gil Martínez, M.A., \& Vorontsova, Y.V. (2020). The Cross-Cultural Communications Impact on Increasing Business Profitability in Digital Technologies Use. $E-$ Management, 3(1), 27-35. doi:10.26425/2658-3445-2020-1-27-35.

Jacoby, S. (2008). The Age of American Unrea- 
son. New York: Pantheon Books.

Morris, D. Z. (2017). Elon Musk Says Artificial Intelligence is the "Greatest Risk We Face as a Civilization". Retrieved from https://finance.yahoo.com/news/elonmusk-says-artificial-intelligence202534848.html?guccounter=1\&guce referrer=aHR0cHM6Ly95YW5kZXgucnUv \&guce referrer_sig=AQAAAJt2r6pXd 88pikbmgReJqA0UZqjv2ZFr3ZkgJ1t NmmgcYbp-kTSRh8ZsCe NPmTx6M1HSw9Lw1o7autTYeR2EBMHkCU INeOk-FdhZIPESjP zkMx8-IzMhLbuSTpbA-xMjYw8g1qHF9vqshPo9eizB7W7kbbUuUSKn83FaMxSCWU.

Ortega y Gasset, J. (1963). Obras Completas $\left(6^{\text {th }}\right.$ ed.). Madrid: Revista de Occidente.

Santos, J. A. (2017). El hombre tecnológico fetiche de la modernidad ampiada. Acuer- dos y desacuerdos con la posmodernidad como resistencia de Jesus Ballesteros. Dikaion, 26(I), 11-30.

Spitzer, M. (2016, February 28). Education and Technology: The Digital Destruction of the Young Brains and Intelligence. Retrieved from https://www.bitlanders.com/blogs/education-and-technologythe-digital-destruction-of-the-youngbrains-and-intelligence/4665718.

Transhumanismo, los arquitectos del future. (2012, March 13). Retrieved from https://naukas.com/2012/03/13/transhu manismo-los-arquitectos-del-futuro/.

Vorontsova, Yu., Arakelyan, A. \& Baranov, V. (2020). Smart Technologies: Unique Opportunities or the Global Challenges of Transhumanism. Wisdom, 2(15), 6875. doi: 10.24234/wisdom.v15i2.335. 